\title{
Machine Learning for All - Introducing Machine Learning in K-12
}

\author{
Christiane Gresse von Wangenheim \\ Department of Informatics and Statistics, Federal University of Santa Catarina, Florianópolis, SC, Brazil, \\ c.wangenheim@ufsc.br
}

Lívia S. Marques

Department of Informatics and Statistics, Federal University of Santa Catarina, Florianópolis, SC, Brazil, livia.marques@grad.ufsc.br

Jean C. R. Hauck

Department of Informatics and Statistics, Federal University of Santa Catarina, Florianópolis, SC, Brazil, jean.hauck@ufsc.br

\begin{abstract}
Although Machine Learning (ML) is integrated today into various aspects of our lives, few understand the technology behind it. This presents new challenges to extend computing education early on including ML concepts in order to help students to understand its potential and limits and empowering them to become creators of intelligent solutions. Therefore, we developed an introductory course to teach basic ML concepts, such as fundamentals of neural networks, learning as well as limitations and ethical concerns in alignment with the $K-12$ Guidelines for Artificial Intelligence. It also teaches the application of these concepts, by guiding the students to develop a first image recognition model of recycling trash using Google Teachable Machine. In order to promote ML education, the interactive course is available online in Brazilian Portuguese to be used as an extracurricular course or in an interdisciplinary way as part of science classes covering recycling topics.
\end{abstract}

\section{KEYWORDS}

Machine Learning, Computing Education, K-12

\section{Introduction}

Artificial Intelligence (AI), which until recently seemed something very distant and of limited access by professionals in technological areas only, today presents itself in common situations, such as spam filters, recommendation mechanisms, chatbots, digital assistants, GPS systems, etc. (Marr, 2019).

Considering this presence and the inevitable impact it has on daily activities, it is essential that people are prepared to deal with both current technologies and those to come. Thus, today, it is necessary to understand Artificial Intelligence not just a consumer, also as a creator of this type of innovation, since it is found practically everywhere (Touretsky et al., 2019)(Kandlhofer et al., 2016). Taking into account also the gap between the growing market demand for AI professionals and the number of professionals available, it is necessary to stimulate interest in careers in this area from an early age on (Forbes, 2019). It is necessary to demystify the idea that AI is complex and inaccessible and to promote initiatives that bring students closer to the understanding and 
production of these technologies. Therefore, we can observe a trend worldwide to include Artificial Intelligence in K-12 curricula. Some countries like Australia and the United Kingdom show significant advances in this direction (Google for Education, 2019) and a considerable amount of AI courses for K-12 have emerged during the last years (Marques et al., 2020). Yet, so far, such efforts are still very scarce in Brazil without instructional units available in the native language as an essential requirement for its application on this educational stage.

According to the K-12 Guidelines for Artificial Intelligence by AI4K12 (Touretsky et al., 2019), AI education encompasses 5 big ideas, including Machine Learning (ML). This includes an understanding of basic ML concepts, as well as limitations and ethical concerns related to ML. And, aiming also at teaching the application of these concepts this covers the development of ML applications encompassing the main phases of a human-centric ML process (Amershi et al., 2019): data management, model learning, evaluation and deployment. In order to facilitate the learning progress of students in this complex knowledge area, the "Use-Modify-Create" cycle (Lyle et al., 2019) commonly used for the progression of learning computing concepts and practices, can also be adopted for ML education. Following this cycle, students start by first using and analysing a given ML model, then remix/modify an existing one, until creating their custom ML models.

Therefore, we present in this article the development of an introductory course to teach basic concepts of AI/Machine Learning as part of computing education in Brazilian schools addressing primarily middle and high school level. Assuming the current lack of ML competencies among K12 students, we initially focus on the "use" stage only of the "Use-Modify-Create" cycle. In order to allow the adoption of the course in an interdisciplinary way in science classes, the course refers to recycling knowledge, contributing also to the fixation of this content.

\section{The course "Machine Learning for All"}

The course has been systematically developed following an instructional design process (Branch, 2009).

\subsection{Context analysis}

The course is focused on teaching ML to students in Brazilian schools aged 10 to 14 years old (middle school) and as well as being applicable as a first contact with ML in high school. On these educational stages, according to the contents established in the Brazilian National Curriculum, we can assume that students are literate in the native language (Brazilian Portuguese) and have some familiarity with the English language, but are not necessarily fluent in English. Regarding natural sciences, students should have developed collaborative thinking and high-level understanding of the natural, technological, and individual world and the relationships between them based on artifacts specific to the natural sciences. In general, students in middle school demonstrate an ageappropriate performance in writing, reading and understanding their experiences, so that they can expand their perception to analyse larger contexts in the following years (MEC, 2018).

According to data from Prova Brasil, 55\% of 9th grade students in Brazilian public schools have at least one computer at home and $42 \%$ of them spend more than three hours a day using digital technologies. This presence of technology in the lives of students rises in the state of Santa Catarina in the south of Brazil to 75\% and 60\%, respectively (INEP, 2017). Thus, students of this age group regularly use the Internet, mobile phones and other technological devices, possessing skills with handling and the ability to learn to use the tools with ease. Specifically, in relation to the use of mobile phones in Brazil, the National Continuous Household Sample Survey indicates that, in $2018,79.3 \%$ of people over 10 years of age had a mobile phone for use, mainly Android (Statcounter, 2019).

With regard to computing education, according to Bordini et al. (2016), computational thinking has started to be studied and introduced in Brazilian schools through individual projects since 2010. 
Yet, most schools still address this issue by treating technology solely as a resource, teaching students to be users, but not necessarily technology creators. And, although there are several initiatives in Brazil aiming at amplifying computing education, it is still mostly limited to individual extracurricular programs (Silva et al., 2018). With respect to Artificial Intelligence and Machine Learning, the curriculum proposed by the Brazilian Computing Association suggests such contents are introduced only in high school in order to understand the fundamentals of artificial and robotic intelligence (SBC, 2018). Machine Learning, however, is not mentioned. Therefore, currently, in practice, AI/ML education on the middle-school level is basically non-existent in Brazil (FECAP, 2020).

According to data from the 2018 school census, $67 \%$ of Brazilian public schools have access to the Internet. In general, there are more than 900,000 computers available for student use. However, only $38 \%$ of schools have a computer lab. Specifically, in Florianópolis, however, the numbers are more positive: $100 \%$ of public schools have access to the internet, with 1,658 computers for students. Computer labs are generally coordinated by an educational technology teacher. These professionals typically have a background in pedagogy with some specialization in the technological area. The other subjects of the K-12 curriculum are taught by teachers in the respective area. However, also in Brazil, there is a lack of teachers qualified in computing education.

Typically, each class in Brazilian schools has a duration of about 45 minutes and the maximum number of students for middle school is 25 students, while 30 students for high school (Florianópolis, 2012).

\subsection{Definition of the course}

The course is targeted at students in middle school without any prior knowledge on Machine Learning. It is assumed that students already have some understanding of basic concepts of algorithms and programming and/or app development with App Inventor as part of previous coding classes. In relation to Machine Learning, the learning objectives are defined in alignment with the K-12 Guidelines for Artificial Intelligence (Touretsky et al., 2019) referring to Big Idea 3 Learning and AI literacy as defined by Long \& Magerko (2020), covering also some general computing topics as proposed by the CSTA (2017) (Table 1).

Table 1. Learning objectives of the course

\begin{tabular}{|l|l|l|l|}
\hline ID & Learning objective & Knowledge area & Source \\
\hline LO1 & Know and identify examples of ML application & ML & $\begin{array}{l}\text { (Touretsky et al., 2019)(Long \& } \\
\text { Magerko, 2020) }\end{array}$ \\
\hline LO2 & $\begin{array}{l}\text { Describe basic ML concepts: what is a neural network, } \\
\text { learning, ML process }\end{array}$ & ML & $\begin{array}{l}\text { (Touretsky et al., 2019)(Long \& } \\
\text { Magerko, 2020) }\end{array}$ \\
\hline LO3 & Identify patterns in data & ML & $\begin{array}{l}\text { (Touretsky et al., 2019)(Long \& } \\
\text { Magerko, 2020) }\end{array}$ \\
\hline LO4 & Simulate the training of a simple neural network & ML & (Touretsky et al., 2019) \\
\hline LO5 & $\begin{array}{l}\text { Collect, clean and label data for the training of a ML model; } \\
\text { understand how ML algorithms are influenced by data }\end{array}$ & ML & $\begin{array}{l}\text { based on human-centric ML } \\
\text { process (Armeshi et al., } \\
\text { 2019)(Long \& Magerko, 2020) }\end{array}$ \\
\hline LO6 & Train a ML model & ML & $\begin{array}{l}\text { (Touretsky et al., 2019)(Long \& } \\
\text { Magerko, 2020) }\end{array}$ \\
\hline LO7 & Evaluate the performance of the ML model & ML & $\begin{array}{l}\text { based on human-centric ML } \\
\text { process (Armeshi et al., } \\
\text { 2019)(Long \& Magerko, 2020) }\end{array}$ \\
\hline
\end{tabular}




\begin{tabular}{|l|l|l|l|}
\hline LO9 & Discuss ethical concerns and the impact of ML on society & $\begin{array}{l}\text { Impacts of } \\
\text { computing/AI }\end{array}$ & $\begin{array}{l}\text { (CSTA, 2017: 1B-IC- } \\
\text { 18)(Touretsky et al., 2019)(Long \& } \\
\text { Magerko, 2020) }\end{array}$ \\
\hline LO10 & Share the developed software system & $\begin{array}{l}\text { Algorithms and } \\
\text { programming }\end{array}$ & $\begin{array}{l}\text { (CSTA, 2016: 1B-AP-12, 1B-AP- } \\
\text { 17, 2-AP-16) }\end{array}$ \\
\hline
\end{tabular}

In addition to providing the student with a perception of the application of ML in our daily life and a basic understanding of how ML works, it aims to take the student to the application level by using and analyzing a ML model on the recognition of recycling trash images. During the practical part, students go through the basic steps of a human-centric ML process, including data management, ML model training, and evaluation. The deployment of the created ML model is planned as an extra activity by creating a mobile app with App Inventor, enabling the student to create a functional and intelligent ML solution.

Aiming at the possibility of an interdisciplinary application, the ML to be developed focuses on the task of the recognition of images of recycling trash. In accordance with the Brazilian National Curriculum this topic is approached in K-12 (Table 2).

Table 2. Interdisciplinary learning objectives (science)

\begin{tabular}{|l|l|l|l|}
\hline ID & Learning objective & $\begin{array}{l}\text { Knowledge } \\
\text { area }\end{array}$ & Source \\
\hline LO11 & $\begin{array}{l}\text { Propose individual and collective initiatives to solve environmental problems in the } \\
\text { city or community, based on the analysis of successful consumption and sustainable } \\
\text { sustainability actions. }\end{array}$ & $\begin{array}{l}\text { Life and } \\
\text { evolution }\end{array}$ & $\begin{array}{l}\text { (MEC, 2018: } \\
\text { EF09CI13) }\end{array}$ \\
\hline
\end{tabular}

The course is organized in the following parts:

- General notions and relevance of ML

- Fundamental concepts

- Make your first ML model (with the additional activity "Make your recycling app!")

- Content review and ML process

- Ethical issues and societal impact of ML

In the first part, $\mathrm{AI} / \mathrm{ML}$ and its application in everyday life is motivated and illustrated through practical demonstration examples. Students are also stimulated to discuss AI applications present in their daily lives in order to perceive the relevance of this knowledge. Part two on fundamental concepts introduces core concepts and ideas of ML and neural networks. This also includes the illustration of data management and simulating learning in a simple neural network example. The part "Make your first ML model!" directs students to develop a ML model for image recognition using Google Teachable Machine. Based on a pre-assembled dataset (with partly "messy" images), the students prepare the dataset, by organizing/labeling the images into recycling categories as well as cleaning the dataset. Then, they train the model. Once trained, they test the model with new images uploaded or captured via webcam, and analyze performance measures, including the accuracy table and confusion matrix presented by Google Teachable Machine. Interpreting the performance results, the students, if necessary, adjust the dataset and/or model training parameters in order to improve the model's performance.

If appropriate in terms of time availability and learning goals, an additional activity can be added in which the students integrate the developed ML model into a mobile application to be built with App Inventor.

Once having applied the ML process, basic concepts and the main phases or the process are revised. The last part of the course includes a critical discussion and reflection on ethical issues and societal impact of ML as well as the motivation with respect to career opportunities in this area.

Table 3. Course syllabus 


\begin{tabular}{|c|c|c|c|c|c|}
\hline \multirow[t]{2}{*}{ Class } & \multirow[t]{2}{*}{ Content } & \multirow{2}{*}{$\begin{array}{l}\text { Learning } \\
\text { objective(s) }\end{array}$} & \multicolumn{3}{|l|}{ Classroom application } \\
\hline & & & Educational method & Educational material & Assessment \\
\hline \multicolumn{6}{|c|}{ General notions and importance } \\
\hline 1. $(2 \mathrm{~h})$ & $\begin{array}{l}\text { Motivation on AI and its application in } \\
\text { daily life }\end{array}$ & LO1, LO9 & \begin{tabular}{|l|} 
Lecture, discussion, \\
hands-on demonstrations
\end{tabular} & $\begin{array}{l}\text { Slides 1.1, } \\
\text { Demonstration: Object Detector } \\
\text { and Classifier app, Quick, draw! } \\
\text { game, vídeo: Object detection } \\
\text { and segmentation }\end{array}$ & Quiz \\
\hline \multicolumn{6}{|l|}{ Basic concepts } \\
\hline 2. (2h) & $\begin{array}{l}\text { Basic concepts of ML: what does it mean } \\
\text { to "learn", ML process: data preparation } \\
\text { (collection, cleaning, labeling), feature } \\
\text { engineering, training }\end{array}$ & $\begin{array}{l}\mathrm{LO} 2, \mathrm{LO} 3 \\
\mathrm{LO} 4\end{array}$ & $\begin{array}{l}\text { Lecture, unplugged } \\
\text { activity }\end{array}$ & $\begin{array}{l}\text { Slides } 2.1 \text {, instructions of } \\
\text { unplugged activity }\end{array}$ & Quiz \\
\hline \multicolumn{6}{|c|}{ Make your first ML model (and app)! } \\
\hline $3.1(1 \mathrm{~h})$ & $\begin{array}{l}\text { Classification of recyclables; data } \\
\text { preparation (cleaning and labeling) }\end{array}$ & $\begin{array}{l}\text { LO3, LO5, } \\
\text { OA11 }\end{array}$ & $\begin{array}{l}\text { Lecture, hands-on } \\
\text { activity (in pairs) }\end{array}$ & $\begin{array}{l}\text { Slides } 3.1, \\
\text { dataset, } \\
\text { Google drive }\end{array}$ & $\begin{array}{l}\text { Quiz, performance-based } \\
\text { assessment of the dataset } \\
\text { prepared }\end{array}$ \\
\hline $3.2(1 \mathrm{~h})$ & Training of the model and evaluation & $\begin{array}{l}\text { LO4, LO6, } \\
\text { LO7 }\end{array}$ & $\begin{array}{l}\text { Lecture, hands-on } \\
\text { activity (in pairs) }\end{array}$ & $\begin{array}{l}\text { Slides } 3.2, \\
\text { Google TM, } \\
\text { evaluation worksheet }\end{array}$ & $\begin{array}{l}\text { Quiz, performance-based } \\
\text { assessment of the model } \\
\text { and evaluation analysis } \\
\& \text { interpretation }\end{array}$ \\
\hline $\begin{array}{l}\text { Extra activity } \\
\text { (4h) }\end{array}$ & $\begin{array}{l}\text { Deployment of the created model in an } \\
\text { app (wireframe available), customization } \\
\text { of the app }\end{array}$ & LO8 & $\begin{array}{l}\text { Hands-on activity (in } \\
\text { pairs) }\end{array}$ & $\begin{array}{l}\text { Slides } 3.3 \text {, } \\
\text { wireframe of the app Recicle! }\end{array}$ & $\begin{array}{l}\text { Performance-based } \\
\text { assessment of the created } \\
\text { app }\end{array}$ \\
\hline $\begin{array}{l}\text { Extra activity } \\
\text { (1h) }\end{array}$ & Sharing of the created app & LO10 & $\begin{array}{l}\text { Hands-on activity (in } \\
\text { pairs), presentation and } \\
\text { discussion }\end{array}$ & Slides 3.4 & $\begin{array}{l}\text { Performance-based } \\
\text { assessment on the } \\
\text { sharing }\end{array}$ \\
\hline \multicolumn{6}{|c|}{ Review of content and ML process } \\
\hline $4.1(1 \mathrm{~h})$ & Revision of the ML concepts and process & $\begin{array}{l}\text { LO1, LO2, } \\
\text { LO5 }\end{array}$ & $\begin{array}{l}\text { Lecture, discussion, } \\
\text { practical activity in pairs }\end{array}$ & Slides 4.1 & Quiz \\
\hline \multicolumn{6}{|c|}{ Ethical issues and societal impact of ML } \\
\hline $4.2(1 \mathrm{~h})$ & $\begin{array}{l}\text { Ethical issues with respect to AI/ML, } \\
\text { limitations, risks and job opportunities }\end{array}$ & LO1, LO9 & Lecture, discussion & $\begin{array}{l}\text { Slides 4.2, demonstration: MIT } \\
\text { Moral Machine, debate cards }\end{array}$ & $\begin{array}{l}\text { Participation in the } \\
\text { debate }\end{array}$ \\
\hline
\end{tabular}

The course can be applied in a face-to-face learning mode either as an extracurricular course or in an interdisciplinary way as part of science classes. It can also be applied in an online distance mode, accessing an interactive course version available online. The online distance version of the course contains the quizzes and other assessment instruments in a simplified way as part of interactive presentations, including multiple-choice questions, drag-and-drop exercises, etc.

\section{Learning assessment}

The assessment of the students' learning is done in different ways (Table 4). This includes:

- Quizzes: simple quizzes (with up to 4 multiple-choice questions, drag-and-drop exercises, etc.) applied at the end of each class (or throughout interactive presentation in the online version of the course)

- Performance-based assessment based on the artefacts created by the students as learning outcomes. For each of the performance-based assessments a rubric is defined aiming at an automated feedback to the student.

Table 4. Student's learning assessment

\begin{tabular}{|l|l|l|l|}
\hline ID & Learning objective & Knowledge area & Assessment \\
\hline LO1 & Know and identify examples of the application of ML & ML & Quiz 1 \\
\hline LO2 & $\begin{array}{l}\text { Describe basic ML concepts: what is a neural network, learning, ML } \\
\text { process }\end{array}$ & ML & Quiz 2 \\
\hline LO3 & Identify patterns in data & ML & Quiz 2 \\
\hline LO4 & Simulate the training of a simple neural network & ML & Quiz 2 \\
\hline
\end{tabular}




\begin{tabular}{|c|c|c|c|}
\hline LO5 & $\begin{array}{l}\text { Collect, clean and label data for the training of a ML model; } \\
\text { understand how ML algorithms are influenced by data }\end{array}$ & ML & Quiz 3, Prepared dataset \\
\hline LO6 & Train a ML model & ML & $\begin{array}{l}\text { Quiz 4, Training } \\
\text { parameters/ML model }\end{array}$ \\
\hline LO7 & Evaluate the performance of the ML model & ML & $\begin{array}{l}\text { Quiz 4, Evaluation } \\
\text { report }\end{array}$ \\
\hline LO8 & Deploy the ML model by developing a mobile app & $\begin{array}{l}\text { ML/Algorithms and } \\
\text { programming/User } \\
\text { interface design }\end{array}$ & \\
\hline LO9 & Discuss ethical concerns and the impact of ML on society & Impacts of computing/AI & Debate \\
\hline LO10 & Share the developed software system & $\begin{array}{l}\text { Algorithms and } \\
\text { programming }\end{array}$ & \\
\hline LO11 & $\begin{array}{l}\text { Propose individual and collective initiatives to solve environmental } \\
\text { problems in the city or community, based on the analysis of successful } \\
\text { consumption and sustainable sustainability actions. }\end{array}$ & Life and evolution & Quiz 3, Prepared dataset \\
\hline
\end{tabular}

Table 5. ML Rubric - Use stage

\begin{tabular}{|c|c|c|c|}
\hline \multirow[t]{2}{*}{ Criterion } & \multicolumn{3}{|l|}{ Performance levels } \\
\hline & Poor - 0 pt & Acceptable - 1 pt & Good- 2 pt \\
\hline \multicolumn{4}{|c|}{ Data management (LO5) } \\
\hline Quantity of images & Less than 5 images per category & 6 to 10 images per category & More than 10 images per category \\
\hline $\begin{array}{l}\text { Relevance of } \\
\text { images }\end{array}$ & $\begin{array}{l}\text { Several images are not related to } \\
\text { the ML task (irrelevant) and/or at } \\
\text { least one image contains unethical } \\
\text { content (violence, nudity, etc.) }\end{array}$ & $\begin{array}{l}\text { One image is irrelevant and } \\
\text { no image containing } \\
\text { unethical content }\end{array}$ & $\begin{array}{l}\text { All images are related to the ML } \\
\text { task and no image containing } \\
\text { unethical content }\end{array}$ \\
\hline $\begin{array}{l}\text { Distribution of the } \\
\text { dataset }\end{array}$ & $\begin{array}{l}\text { Quantities of images by category } \\
\text { vary greatly }\end{array}$ & $\begin{array}{l}\text { Quantities of images by } \\
\text { category vary little }\end{array}$ & $\begin{array}{l}\text { All categories have the same } \\
\text { quantity of images }\end{array}$ \\
\hline $\begin{array}{l}\text { Labeling of the } \\
\text { images }\end{array}$ & $\begin{array}{l}\text { Less than } 20 \% \text { of the images have } \\
\text { been labeled correctly }\end{array}$ & $\begin{array}{l}\text { Between } 20 \text { and } 99 \% \text { of the } \\
\text { images have been labeled } \\
\text { correctly }\end{array}$ & All images were labeled correctly \\
\hline Data cleaning & $\begin{array}{l}\text { There are several messy images } \\
\text { (out of focus, several objects in the } \\
\text { same image, etc.) }\end{array}$ & There is one messy image & $\begin{array}{l}\text { No messy images were included in } \\
\text { the dataset }\end{array}$ \\
\hline \multicolumn{4}{|c|}{ Model training (LO6) } \\
\hline Training & The model was not trained & $\begin{array}{l}\text { The model was trained using } \\
\text { standard parameters }\end{array}$ & $\begin{array}{l}\text { The model was trained with } \\
\text { adjusted parameters (e.g., epoch, } \\
\text { batch size, learning rate) }\end{array}$ \\
\hline \multicolumn{4}{|c|}{ Interpretation of performance (LO7) } \\
\hline $\begin{array}{l}\text { Tests with new } \\
\text { objects }\end{array}$ & No object tested & $1-2$ object tested & More than 2 objects tested \\
\hline $\begin{array}{l}\text { Interpretation of } \\
\text { tests }\end{array}$ & Wrong interpretation & - & Correct interpretation \\
\hline $\begin{array}{l}\text { Accuracy } \\
\text { interpretation }\end{array}$ & $\begin{array}{l}\text { Categories with low accuracy are } \\
\text { not identified correctly and } \\
\text { incorrect interpretation wrt. he } \\
\text { model }\end{array}$ & $\begin{array}{l}\text { Correctly identified } \\
\text { categories with low accuracy, } \\
\text { but incorrect interpretation } \\
\text { wrt. he model }\end{array}$ & $\begin{array}{l}\text { Correctly identified categories with } \\
\text { low accuracy and the consequent } \\
\text { interpretation wrt. he model }\end{array}$ \\
\hline $\begin{array}{l}\text { Interpretation of } \\
\text { the confusion } \\
\text { matrix }\end{array}$ & $\begin{array}{l}\text { Misclassifications are not identified } \\
\text { correctly and incorrect } \\
\text { interpretation wrt. he model }\end{array}$ & $\begin{array}{l}\text { Correctly identified } \\
\text { misclassifications, but } \\
\text { incorrect interpretation wrt. } \\
\text { he model }\end{array}$ & $\begin{array}{l}\text { Correctly identified } \\
\text { misclassification and the consequent } \\
\text { interpretation wrt. he model }\end{array}$ \\
\hline $\begin{array}{l}\text { Adjustments / } \\
\text { Improvements } \\
\text { made }\end{array}$ & $\begin{array}{l}\text { No new development iterations } \\
\text { have been reported }\end{array}$ & $\begin{array}{l}\text { A new iteration with changes } \\
\text { to the dataset and/or training } \\
\text { parameters has been reported }\end{array}$ & $\begin{array}{l}\text { Several iterations with changes to } \\
\text { the dataset } \text { and/or training } \\
\text { parameters were reported }\end{array}$ \\
\hline
\end{tabular}

\subsection{Development of the course material}


In accordance with the course objective and syllabus, educational material has been developed in Brazilian Portuguese as summarized in Table 6.

Table 6. Educational materials

Teacher material

Slides

Support material for the unplugged, practical activities and debate

Indication of online demonstrations and tools

Quizzes including course syllabus, rubrics etc.
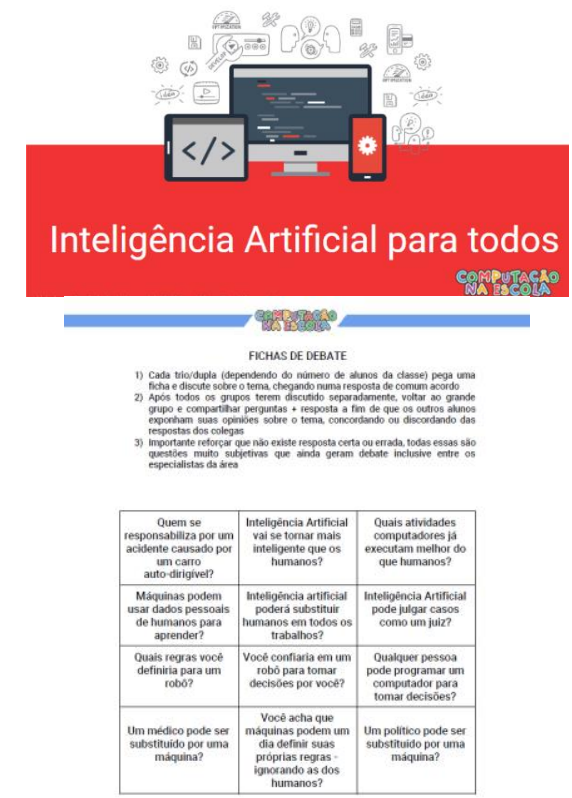

such as Google Teachable Machine, MIT Moral Machine etc.

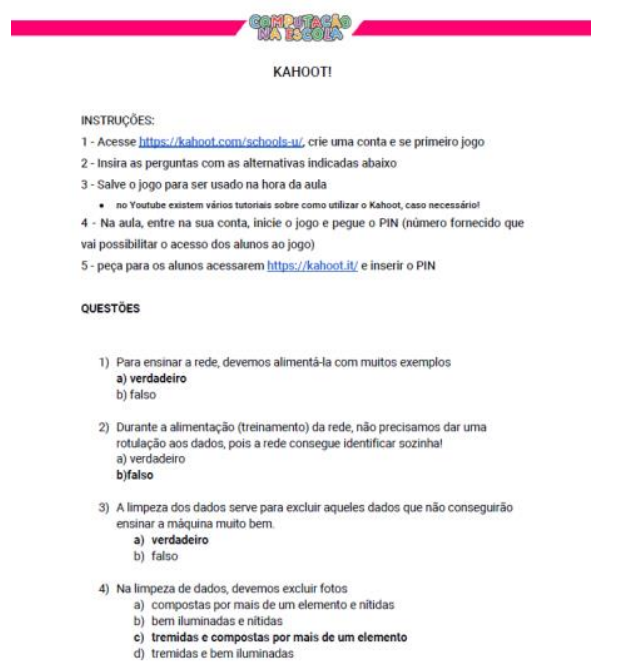

The educational material as well as the course in an online version in form of interactive activities (Figure 1) at http://cursos.computacaonaescola.ufsc.br/cursos/curso-mlparatodos/. 

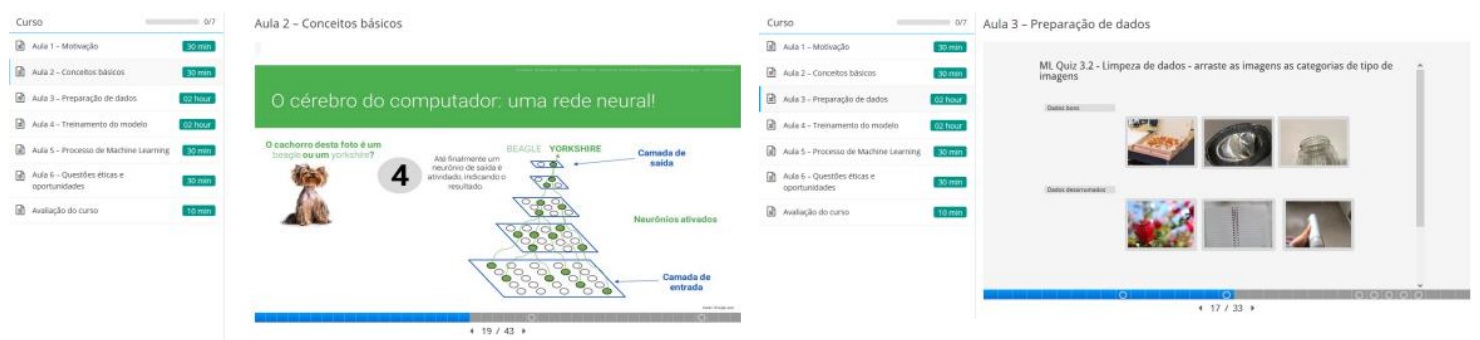

Figure 1. Online course

\section{Conclusion}

The course "Machine Learning for All" was created with the objective of contemplating a current social demand: the dissemination of knowledge about Artificial Intelligence and, specifically, Machine Learning, starting in school. For this purpose, the course enables the teaching and learning of basic Machine Learning concepts in Brazilian schools, targeting primarily middle school and being also applicable as an introductory activity 


\section{ACKNOWLEDGEMENTS}

This work was supported by CNPq (Conselho Nacional de Desenvolvimento Científico e Tecnológico www.cnpq.br), an entity of the Brazilian government focused on scientific and technological development.

\section{REFERENCES}

Armeshi, S. et al. Software Engineering for Machine Learning: A Case Study. Proc. of the 41st International Conference on Software Engineering: Software Engineering in Practice, IEEE Press, 2019, 291-300.

Bordini, A. et al. Computação na Educação Básica no Brasil: o Estado da Arte. RITA, 23(2), 2016.

Branch, R. 2009. Instructional design: The ADDIE approach. 2nd ed. Athens: Springer.

CSTA. CS Standards. 2017. https://www.csteachers.org/page/standards.

Long, D. and Magerko, B. What is AI Literacy? Competencies and Design Considerations. Proc. of the Conference on Human Factors in Computing Systems, ACM, New York, NY, USA, 2020, 1-16.

FECAP. Inteligência Artificial chega à grade do ensino técnico do Brasil, 2020. https://www.fecap.br/2020/01/13/inteligencia-artificial-chega-a-grade-do-ensino-tecnico-do-brasil/

Florianópolis, Lei Municipal no 9124, de 28 de nov. 2012. Dispõe sobre o número de alunos por sala de aula. https://leismunicipais.com.br/a/sc/f/florianopolis/lei-ordinaria/2012/912/9124/ lei-ordinaria-n-9124-2012dispoe-sobre-o-numero-de-alunos-por-sala-de-aula.

Forbes. AI goes to high school. 2019. https://www.forbes.com/sites/insights-intelai/2019/05/22/ai-goes-tohigh-school/\#68826e3f1d0c

Google for Education. International CS Education 2019. https://docs.google.com/spreadsheets/d/1SE7hGK5CkOlAf6oEnqk0DPr8OOSdyGZmRnROhr0XHys/edit\# gid $=218360034$

IBGE. Pesquisa Nacional por Amostra de Domicílios Contínua 2018. https://www.ibge.gov.br/estatisticas/sociais/populacao/17270-pnadcontinua.html?edicao $=27138 \& \mathrm{t}=$ resultados.

INEP. Sinopses Estatísticas da Educação Básica. 2017. http://inep.gov.br/web/guest/sinopses-estatisticas-daeducacao-basica.

Lytle, N. et al. Use, Modify, Create: Comparing Computational Thinking Lesson Progressions for STEM Classes. Proc. of the Conference on Innovation and Technology in Computer Science Education, ACM, 2019, 395-401.

Kandlhofer, M., Steinbauer, G., Hirschmugl-Gaisch, S., Huber, P. Artificial Intelligence and Computer Science in Education: From Kindergarten to University. Proc. of IEEE Frontiers in Education Conference, Erie, PA, USA, 2016.

Marques, L. S., Gresse von Wangenheim, C., Hauck, J. C. R. Teaching Machine Learning in School: A Systematic Mapping of the State of the Art. Informatics in Education, 19(2), 2020.

Marr, B. The 10 Best Examples of How AI is Already Used in our Everyday Life. 2019. https://www.forbes.com/sites/bernardmarr/2019/12/16/the-10-best-examples-of-how-ai-is-already-used-inour-everyday-life/\#47323dec1171.

MEC. Base Nacional Comum Curricular, 2018. http://basenacionalcomum.mec.gov.br/abase/.

SBC. Diretrizes para ensino de Computação na Educação Básica. 2018. https://www.sbc.org.br/educacao/diretrizes-para-ensino-de-computacao-na-educacao-basica.

Silva, K. d. S.; Pereira, N. P.; Odakura, V. Mapeamento Sistemático: estratégias para o ensino aprendizagem do pensamento computacional no Brasil. Nuevas Ideas en Informática Educativa, 14, 2018, 319-329. 
Statcounter. Mobile Operating System Market Share in Brazil - June 2020. https://gs.statcounter.com/osmarket-share/mobile/brazil.

Touretzky, D. S., Gardner-McCune, C., Martin, F., Seehorn, D. K-12 Guidelines for Artificial Intelligence: What Students Should Know. Proc. of the ISTE Conference, Philadelphia, PA, USA, 2019. 